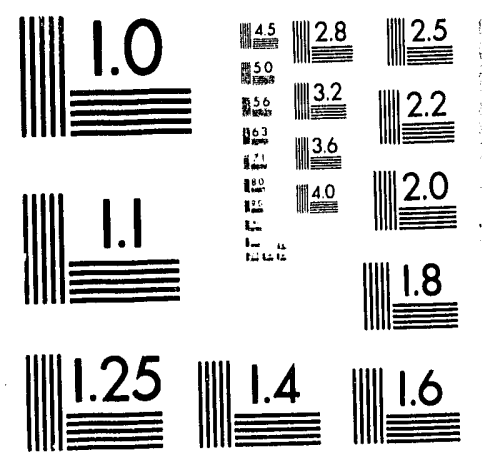



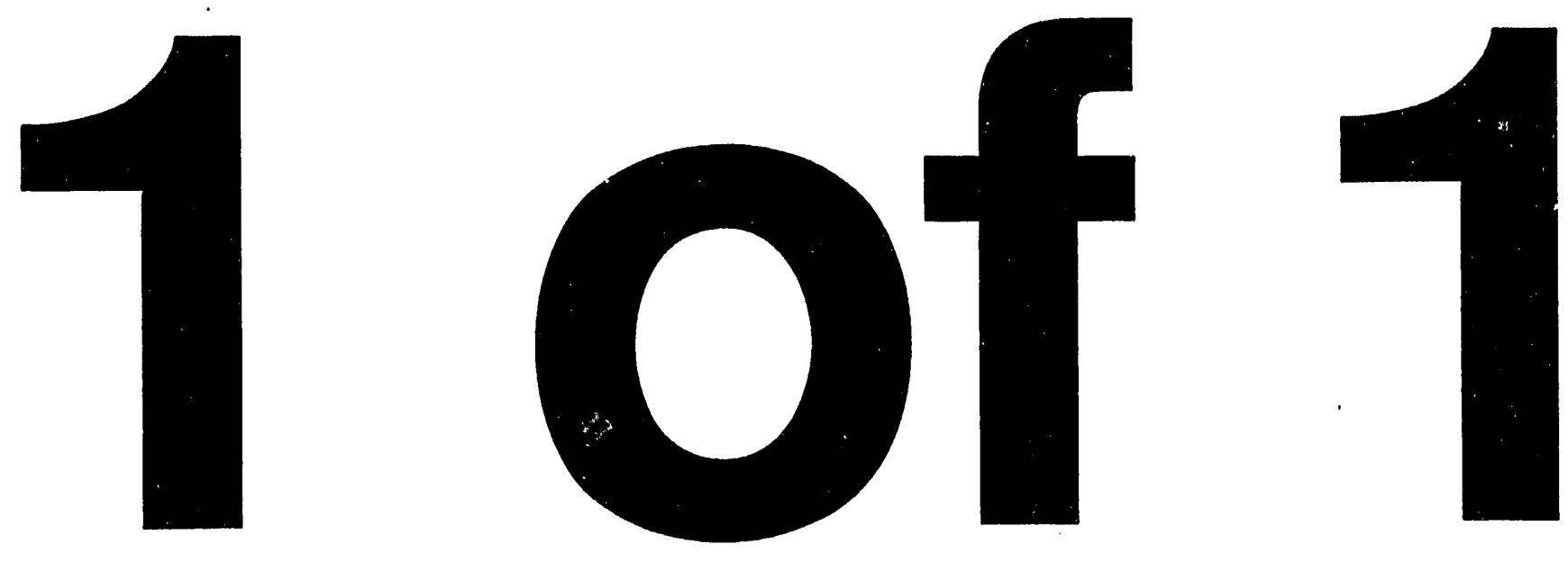
DOE/RL-93-64

Revision 0

UC. 630

\section{Sodium Dichromate Expedited Response Action Assessment}

Date Published

September 1993

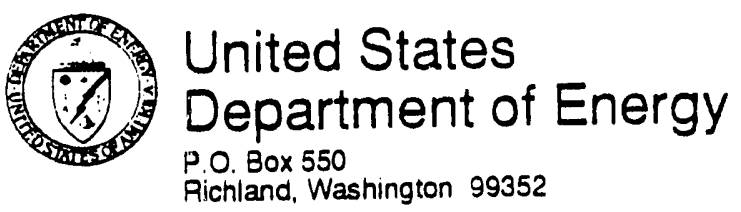

P.O. Box 550
Richland. Washington 99352 


\section{CONTENTS}

1.0 INTRODUCTION . . . . . . . . . . . . . . . . . . . . . . . 1

2.0 REMEDIATION DESCRIPTION ............. 1

2.1 LOCATION AND PHYSICAL DESCRIPTION . . . . . . . . . . . . 1

2.2 CONTAMINANTS OF CONCERN . . . . . . . . . . . . . . 3

2.3 ACTION MEMORANDUM . . . . . . . . . . . . . . . . . 3

2.4 HAZARD REMOVAL ACTIVITIES .............. 3

3.0 RESULTS . . . . . . . . . . . . . . . . . . . . . . . 5

3.1 FIELD SCREENING . . . . . . . . . . . . . . . 5

3.1.1 Method A: Fast Turnaround for Chromium(VI) . . . . 5

3.1.2 Method B: Fast Turnaround for Chromium(VI) . . . . 5

3.1.3 Method C: Water Leach for Soluble Chromium(VI)
in Soil . . . . . . . . . . . . . . . 6

3.1.4 Method D: Chromium(VI) . . . . . . . . . . . 6

3.1.5 Method E: Total Chronium . . . . . . . . . . . . . 6

3.2 OFFSITE LABORATORY ANALYSIS . . . . . . . . . . . . 6

3.3 SAMPLING CONCLUSIONS . . . . . . . . . . . . . 9

4.0 COST ANALYSIS . . . . . . . . . . . . . . . . . . . 9

5.0 REFERENCES . . . . . . . . . . . . . . . . . . 10

APPENDIX A - ACTION AGREEMENT MEMORANDUM . . . . . . . . . . . A-1

\section{FIGURES :}

1 Sodium Dichromate Barrel Landfill Site Map . . . . . . . . . . 2

2 Geophysical Anomaly (Zone) Locations . . . . . . . . . . . . . . l $_{4}$

3 Field Screening Chromium(VI) Sample Results . . . . . . . . . . 11

4 Chromium(VI) Sample Results . . . . . . . . . . . . . . . 12

5 Field Screening Chromium(VI) Spiked Sample Results . . . . . . . 13

6 Total Chromium Sampling Comparison ............. 14

\section{TABLES:}

1 Sodium Dichromate ERA Cleanup Activity Sample Data Table . . . . . 7

2 Sodium Dichromate ERA Cleanup Activity QA Spike Data Table . . . . . . 9 
DOE/RL-93-64, Rev. 0

\subsection{INTRODUCTION}

The U.S. Environmental Protection Agency (EPA) and Washington Department of Ecology (Ecology) recommended that the U.S. Department of Energy (DOE) perform an expedited response action (ERA) for the Sodium Dichromate Barrel Disposal Landfill. The ERA lead regulatory agency is Ecology and EPA is the support agency. The ERA was conducted in accordance with the applicable sections of 40 CFR 300, Subpart E (EPA 1990), the Hanford Federal Facility Agreement and Consent Order (Part 3, Article XIII, Section 38) (Ecology et al. 1991), the Comprehensive Environmental Response, Compensation, and Liability Act (CERCLA), the Resource Conservation and Recovery Act (RCRA), and the Washington Model Toxics Control Act (MTCA).

The ERA was categorized as non-time-critical, which required preparation of an engineering evaluation and cost analys is (EE/CA). The EE/CA was included in the ERA proposal. The EE/CA is a rapid, focused evaluation of available technologies using specific screening factors to assess feasibility, appropriateness, and cost.

The ERA goal is to reduce the potential for any contaminant migration from the landfill to the soil column, groundwater, and Columbia River. Since the Sodium Dichromate Barrel Disposal Landfill is the only waste site within the operable unit, the removal action may be the final remediation of the 100-IU-4 Operable Unit.

This ERA process started in March 1992. The ERA proposal went through a parallel review process with Westinghouse Hanford Company (WHC), DOE Richland Operations (RL), EPA, Ecology, and a 30-day public comment period. Ecology and EPA issued an Action Agreement Memorandum in March 1993 (Appendix A). The memorandum directed excavation of all anomalies and disposal of the collected materials at the Hanford Site Central Landfill. Primary field activities were completed by the end of April 1993. Final waste disposal of a minor quantity of hazardous waste was completed in July 1993.

\subsection{REMEDIATION DESCRIPTION}

\subsection{LOCATION AND PHYSICAL DESCRIPTION}

The Sodium Dichromate Barrel Disposal Landfill is located in a small depression between the 100-D and 100-H Areas (Figure 1). The landfill was used in 1945 for disposal of crushed, empty, sodium dichromate barrels. The 100-IU-4 Operable Unit is a source operable unit; the groundwater beneath it is included in the 100-HR-3 Operable Unit.

Historical documentation for the site (dimensions, usage, and waste volume) is not available. The Waste Information Data System (WHC 1991) assumes that the crushed barrels contained $1 \%$ residual sodium dichromate at burial time and that only crushed barrels are buried at the site. Burial depth is shallow since visual inspection reveals numerous barrel debris on the surface. 
DOE/RL-93-64, Rev. 0

Figure 1. Sodium Dichromate Barrel Landfill Site Map.

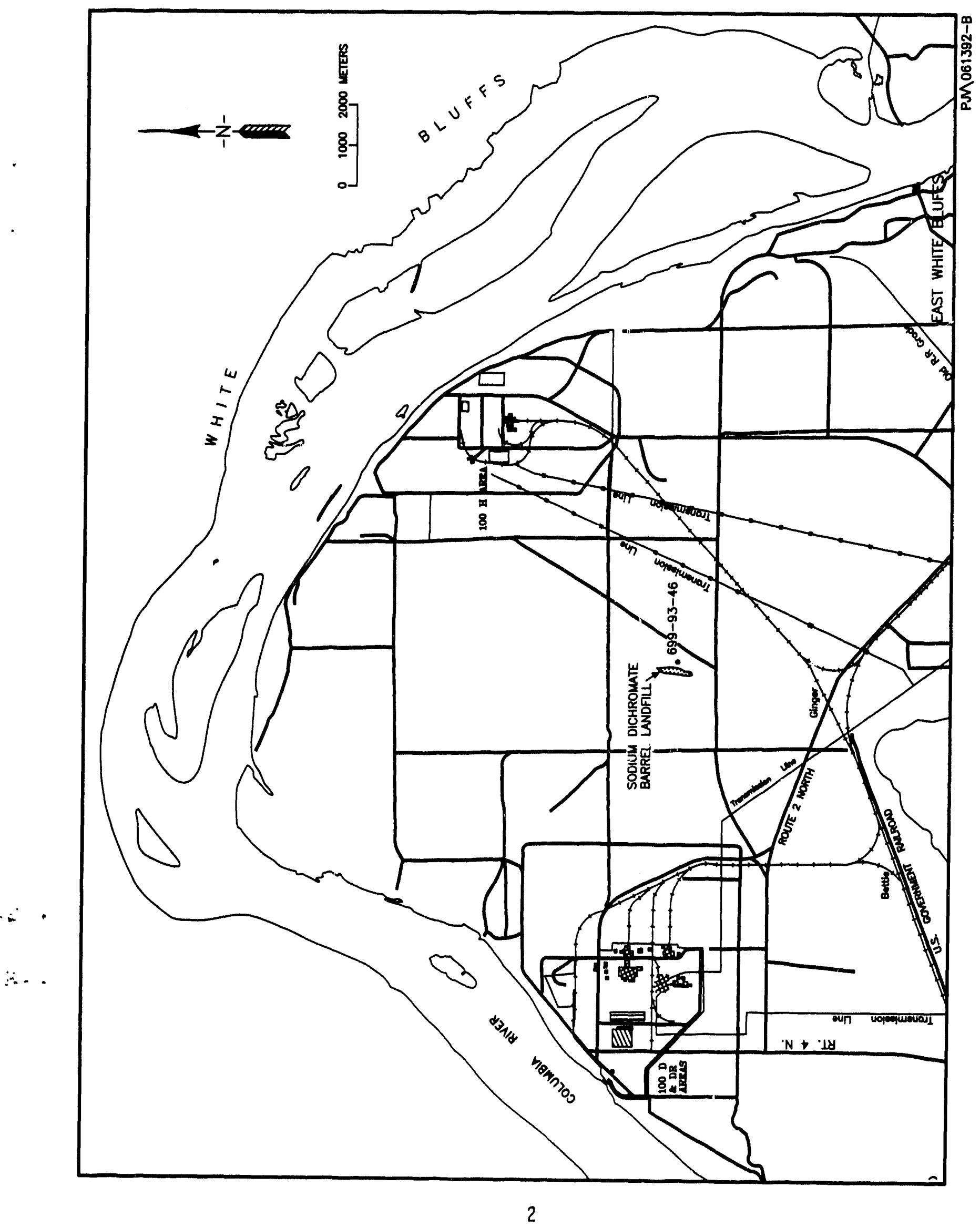


DOE/RL-93-64, Rev. 0

Limited characterization activities (DOE-RL 1993) confirmed the presence of the barrels. A variety of homestead debris (tin cans, wire, etc.) was also found on the site. The overall area of immediate concern is approximately 1,540 by $300 \mathrm{ft}$. Site geophysical characterization identified approximately 144 isolated anomalies plus 11 major anomalies referred to as zones. These zones have a potential for high concentrations of buried debris (Figure 2 ). Characterization activities showed some anomalies to be natural geologic features.

\subsection{CONTAMINANTS OF CONCERN}

Based on previous radiological surveys of the site, the work area is considered nonradioactive. The primary hazardous constituents of concern are chromium(VI) and total chromium. Sample data from 1 imited characterization do not indicate elevated levels of chromium at the site.

During removal activities, small quantities of asbestos, waste $0 i 1$, and a discarded battery were found. These were disposed of as hazardous waste.

\subsection{ACTION MEMORANDUM}

The Action Memorandum (Appendix A) required excavation of all anomalies and disposal of the materials at the Central Landfil1 (Alternative $C$ ).

\subsection{HAZARD REMOVAL ACTIVITIES}

Anomaly excavation activities began on March 17, 1993 and ended Apri1 26, 1993. Conventional earthmoving equipment (trackhoe, small backhoe, water truck, and dump truck) were used to exhume the 1 andfill and transport the excavated debris to the Central Landfil1.

A total of 144 anomalies and 11 subsurface zones were inspected and excavated. A small backhoe excavated the 144 anomalies. The 11 zones were excavated by a large trackhoe. Geological formations (compacted gravel and cobble layers) and homestead debris were found at seven of the zones ( $A, B, F$, $H, I, J$ and $K)$, and at 118 anomalies.

Four zones ( $C, D, E$, and $G$ ) and 26 anomalies contained crushed, empty sodium dichromate barrels. The zones were excavated to a 7-ft depth before undisturbed soil was found. Buried drums were scattered throughout the zones. The typical anomaly depth did not exceed $4 \mathrm{ft}$ and usually consisted of one or two buried drums. About 5,000 crushed barrels and various homestead debris (wire fencing, wooden posts, and other miscellaneous debris) were removed and transported to the Central Landfill.

Besides containing crushed drums, the four zones included some loose asbestos, one crushed drum full of asbestos, two 5-gal roofing tar cans, one paint can, and used $0 i l$ and grease (about 0.5 gal total). These materials were placed in three 55-gal drums and sent to an offsite disposal facility. The drum of asbestos went to the Central Landfill asbestos section for disposal. 
DOE/RL-93-64, Rev. 0

Figure 2. Geophysical Anomaly (Zone) Locations.
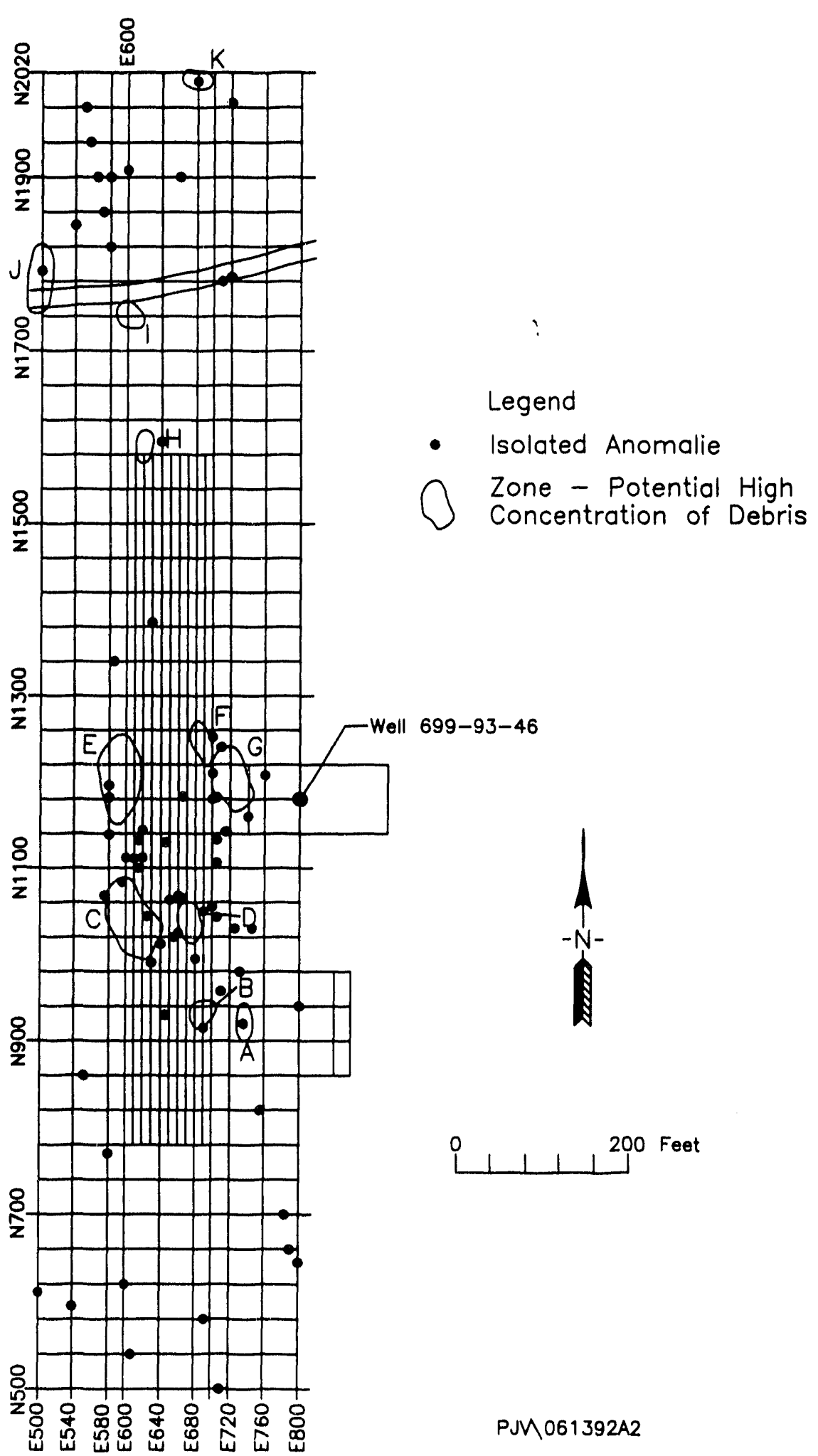
Soil samples collected during the cleanup activities were analyzed for chromium(VI) and total chromium. The zone sample locations used a 30 - by 30-ft grid with samples collected at the excavation bottom. Zone samples were collected from about the center of the backhoe bucket for excavated sites

(>4 ft deep). The anomaly soil samples were collected directly underneath the barrel(s). Each soil sample collection was homogenized in a clean, stainlesssteel bowl before placement in sample bottles.

\subsection{RESULTS}

The soil samples were analyzed by a variety of screening methods and offsite laboratory methods for chromium(VI) and total chromium. The objective of using a variety of methods was to demonstrate the effectiveness of field screening methods, relative to laboratory analysis, and to provide a basis for comparison of the various methods.

\subsection{FIELD SCREENING}

Several screening analytical methods were used to evaluate/compare the effectiveness of each. One method was carried out onsite immediately after sample collection and others were carried out at various onsite laboratories on a fast-turnaround basis. Each method is briefly summarized below. Results of each method are summarized in Tables 1 and 2 and Figures 3 through 6 .

\subsubsection{Method A: Fast Turnaround for Chromium(VI)}

This method uses a modification of the EPA toxicity leach procedure (EPA 1986, Method 1310) followed by calorimetric determination of chromium(VI) in solution by the diphenylcarbazide method. The calorimetric determination is a modification of EPA Method 7196. First, a 10-g aliquot of soil was weighed out and added to $160 \mathrm{~mL}$ of water in a glass jar. The sample was agitated and the $\mathrm{pH}$ was checked. If the $\mathrm{pH}$ was $>5,0.5 \mathrm{~N}$ acetic acid was added dropwise to attain a pH of 5 . The $\mathrm{pH}$ was checked at intervals for $6 \mathrm{hr}$ and carefully adjusted to 5 as necessary. After a total agitation time or $16 \mathrm{hr}$, the leachate was filtered through a $0.45-\mu$ filter, and the diphenylcarbazide reagent was added to a $25-\mathrm{mL}$ aliquot. After a 5-min color development time, chromium(VI) content was determined using a spectrophotometer to measure absorbance at $540 \mathrm{~nm}$, following manufactures procedures.

\subsubsection{Method B: Fast Turnaround for Chromium(VI)}

In this method, $1 \mathrm{~g}$ of soil was added to $100 \mathrm{~mL}$ of water and placed in an ultrasonic bath for $2 \mathrm{hr}$. The sample was allowed to stand for an additional $2 \mathrm{hr}$ before filtration with a 0.45- $\mu$ filter. Acid and diphenylcarbazide were added. After a 10-min color development period, chromium(VI) concentration in the extract was determined with a spectrophotometer. 


\subsubsection{Method C: Water Leach for Soluble Chromium(VI) in Soil}

This method was developed specifically for onsite determination of water-soluble chromium(VI) in soils. It is intended as a field screening method for sites where sodium dichromate is listed as the contaminant of concern.

A 20-g aliquot soil sample was weighed out in "as-received" condition and added to $40 \mathrm{~mL}$ of water in a 1-0z, wide-mouth glass jar. A teflon-coated stir bar was added and the jar was placed on a hotplate/stirrer unit with the heat set at "low" and stir set at "high" for $15 \mathrm{~min}$. At the end of the 15-min extraction period, the soil/water mixture was allowed to settle for a few minutes and then filtered with a $0.45-\mu$ filter. In a disposable beaker, $10 \mathrm{~mL}$ of the resulting filtrate was added deionized water to a total volume of $25 \mathrm{~mL}$. A reagent (diphenylcarbazide with buffer) pillow was added and the mixture was stirred well with a disposable plastic stir rod. After a 10-min color development period, the solution was analyzed using a filter photometer. The result obtained with the filter photometer was corrected to account for dilution and reported as parts per million chromium(VI).

\subsubsection{Method D: Chromium(VI)}

In this method, $1 \mathrm{~g}$ of soil and $1 \mathrm{~mL}$ of demineralized water were placed in an ultrasonic bath for $10 \mathrm{~min}$. Following the ultrasonic mixing, the sample was centrifuged for $10 \mathrm{~min}$. A $100-\mu \mathrm{L}$ al iquot was transferred to a polypropylene film and evaporated to dryness. The sample was then analyzed for total chrome by $x$-ray fluorescence (XRF). The assumption is that only soluble chromium(VI) will be transferred to the film.

\subsubsection{Method E: Total Chromium}

The soil samples were processed and analyzed by XRF spectroscopy. Five hundred milligrams of the as-received sample were air dried and ground to about 300 mesh and mounted in 35- mm slide holders between two sheets of 0.25-mil polypropylene for XRF. Total chrome was determined using iron and zirconium secondary targets.

\subsection{OFFSITE LABORATORY ANALYSIS}

In addition to the above chromium(VI) and total chromium field screening and rapid turnaround analyses, confirmatory samples were submitted to offsite laboratories for analys is using EPA Method 7179 for chromium(VI) and EPA Contract Laboratory Program (CLP) protocols for total chromium.

A composite sample of all collected waste $0 i 1$ was analyzed for waste designation purposes using CERCLA CLP inductively coupled plasma (ICP) metals (e.g., lead, selenium, arsenic, and mercury) and polychlorinated biphenyls.

The paint material was analyzed for ICP metals (including lead, selenium, arsenic, and mercury). 
Table 1. Sodium Dichromate ERA Clearup Activity Sample Data Table.

(Page 1 of 2)

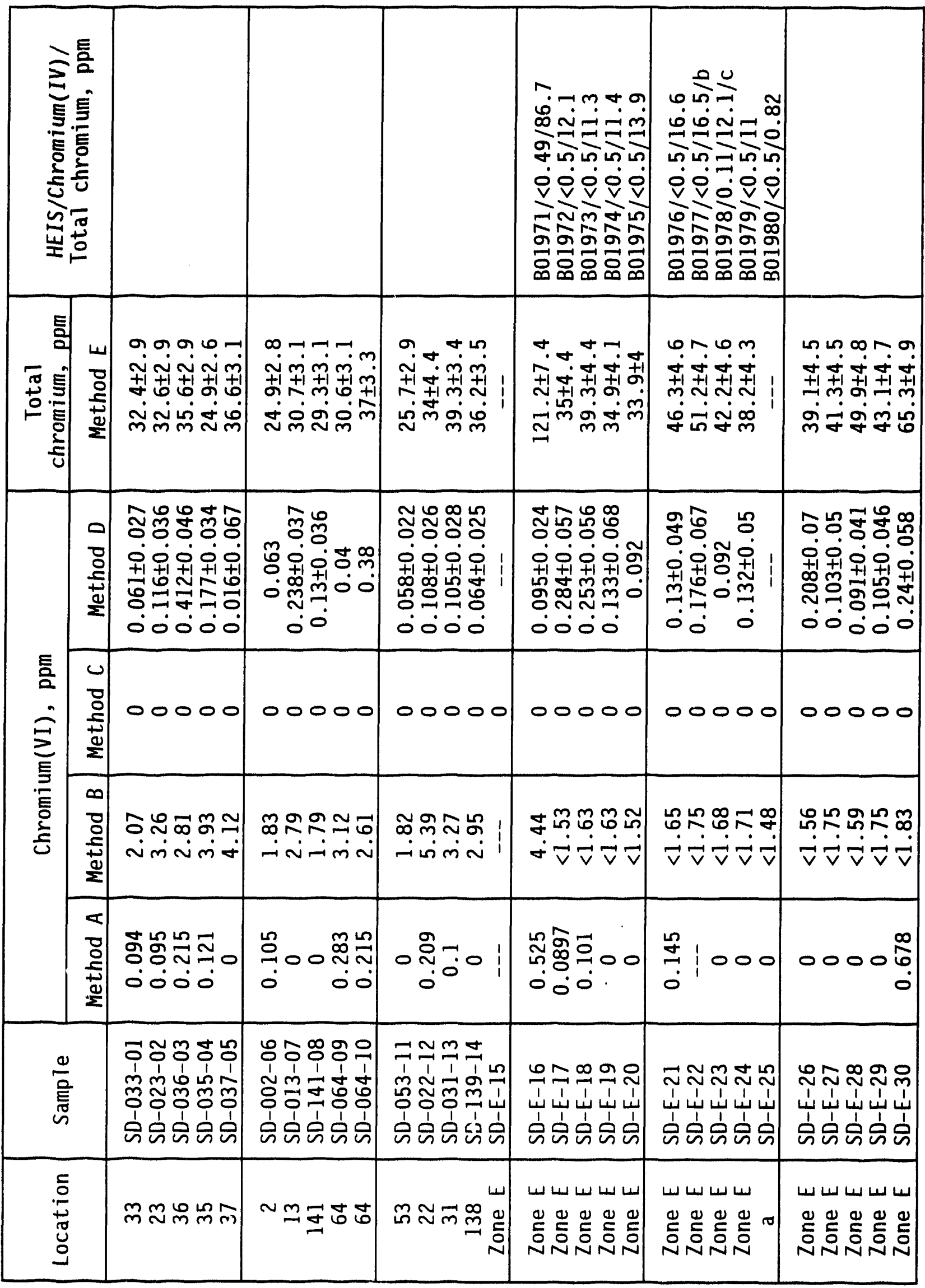


Table 1. Sodium Dichromate ERA Cleanup Activity Sample Data Table.

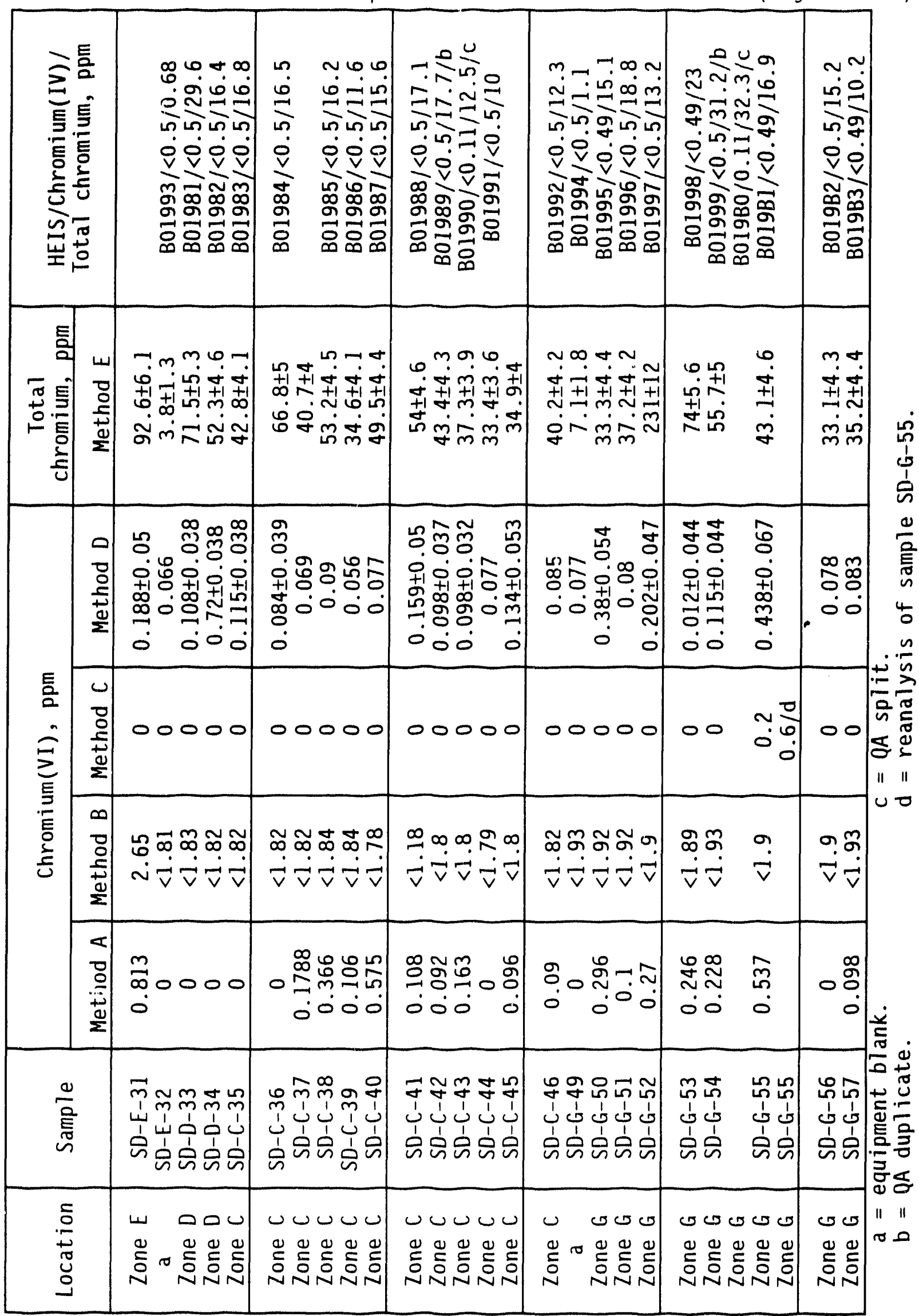


Table 2. Sodium Dichromate ERA Cleanup Activity

QA Spike Data Table.

\begin{tabular}{|c|c|c|c|c|}
\hline \multirow{2}{*}{ Sample } & \multicolumn{4}{|c|}{ Chromium(VI), ppm } \\
\cline { 2 - 5 } & Sample Value & Method A & Method B & Method C \\
\hline S10 & 0.5 & 0.49 & 0.24 & 0.2 \\
S11 & 0 & 0 & 0.146 & 0 \\
S12 & 0.25 & 0.21 & 0.273 & 0.2 \\
\hline S13 & 2.50 & 2.3 & 0.788 & 1.2 \\
S14 & 1.00 & 0.98 & 0.433 & 0.6 \\
S15 & 5.00 & 4.7 & 1.67 & 4.0 \\
\hline
\end{tabular}

\subsection{SAMPLING CONCLIISIONS}

The field screening and offsite laboratory results did not identify any chromium(VI) and total chromium levels that constituted a hazardous condition. Field screening demonstrated cost effectiveness, accuracy, and timely response in expediting cleanup actions.

The MTCA (WAC 173-340-740) Method A chromium cleanup level for soils is $100 \mathrm{mg} / \mathrm{kg}$ or $100 \mathrm{ppm}$. Because sample results are below regulatory cleanup limits, a risk assessment is not necessary as health risk at the limit is negligible.

The waste oil and paint results were used to designate the hazardous waste disposal process required to dispose of the three hazardous waste drums filled during excavation activities.

\subsection{COST ANALYSIS}

ERA Activity

\section{Site Characterization}

Labor

Materials and Supplies

Administration

Analytical Services

Subtotal

ERA Proposal

Labor

Materials and Supplies

Administration

Subtotal
Estimated

$\$ 132.0$

18.5

206.4

10.0

$\$ 366.9$

$\$ 64.5$

10.5

66.3

$\$ 141.3$
Actual

Net

$\$ \quad 19.1$

1.7

95.0

16.8

12.5

$\$ 212.1$

111.4

$\frac{-2.5}{\$ 144.8}$

$\$ 40.3$

5.0

42.7

$\$ \frac{42.7}{38.0}$

$\$ 24.2$

5.5

23.8

$\$ 53.5$ 
DOE/RL-93-64, Rev. 0

ERA Activity Estimated Actual Net

Cleanup Implementation and Closeout Labor

Materials and Supplies

Administration

Analytical Services

Waste Disposal

Subtotal

Total

\begin{tabular}{rrr}
$\$ 146.3$ & $\$ 138.8$ & $\$ 7.5$ \\
21.4 & 22.9 & -1.5 \\
163.7 & 167.8 & -4.1 \\
72.1 & 57.7 & 14.4 \\
18.1 & $\frac{18.1}{\$ 405.3}$ & $\$ \frac{0.0}{16.3}$ \\
\hline$\$ 421.6$ & $\overline{\$ 705.4}$ & $\$ 214.6$
\end{tabular}

\subsection{REFERENCES}

DOE-RL, 1993, Sodium Dichromate Barrel Landfill ERA Proposal, DOE/RL 93-25, U.S. Department of Energy-Richland Field Office, Richland, Washington.

Ecology, EPA, and DOE, 1989 et seq., Hanford Federal Facility Agreement and Consent Order, Washington Department of Ecology, U.S. Environmental Protection Agency, and U.S. Department of Energy, 01ympia, Washington.

EPA, 1990, National $0 i 7$ and Hazardous Substances Pollution Contingency Plan, Title 40, Code of Federal Regulations, Part 300, U.S. Environmental Protection Agency, Washington, D.C.

Hazardous Waste Cleanup--Model Toxics Control Act, 1989, Revised Code of Washington, Chapter 70.105D, Washington State Department of Ecology, Olympia, Washington.

WHC, 1991, WIDS Database Field Descriptions and Data, WHC-MR-0056, Rev. 1, Westinghouse Hanford Company, Richland, Washington. 
D0E/RL-93-64, Rev. 0

Figure 3. Field Screening Chromium(VI) Sample Results.

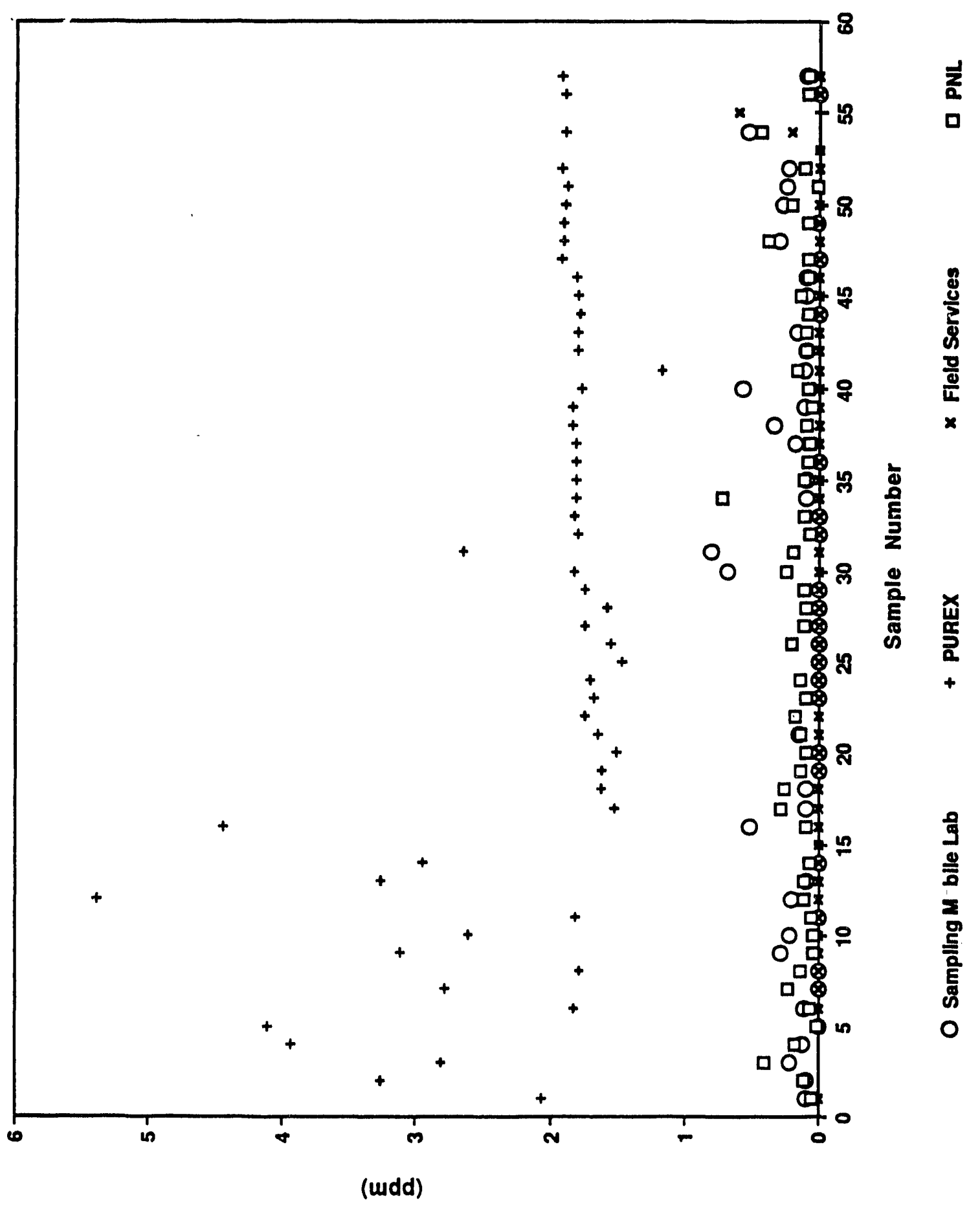


DOE/RL-93-64, Rev. 0

Figure 4. Chromium(VI) Sample Results.

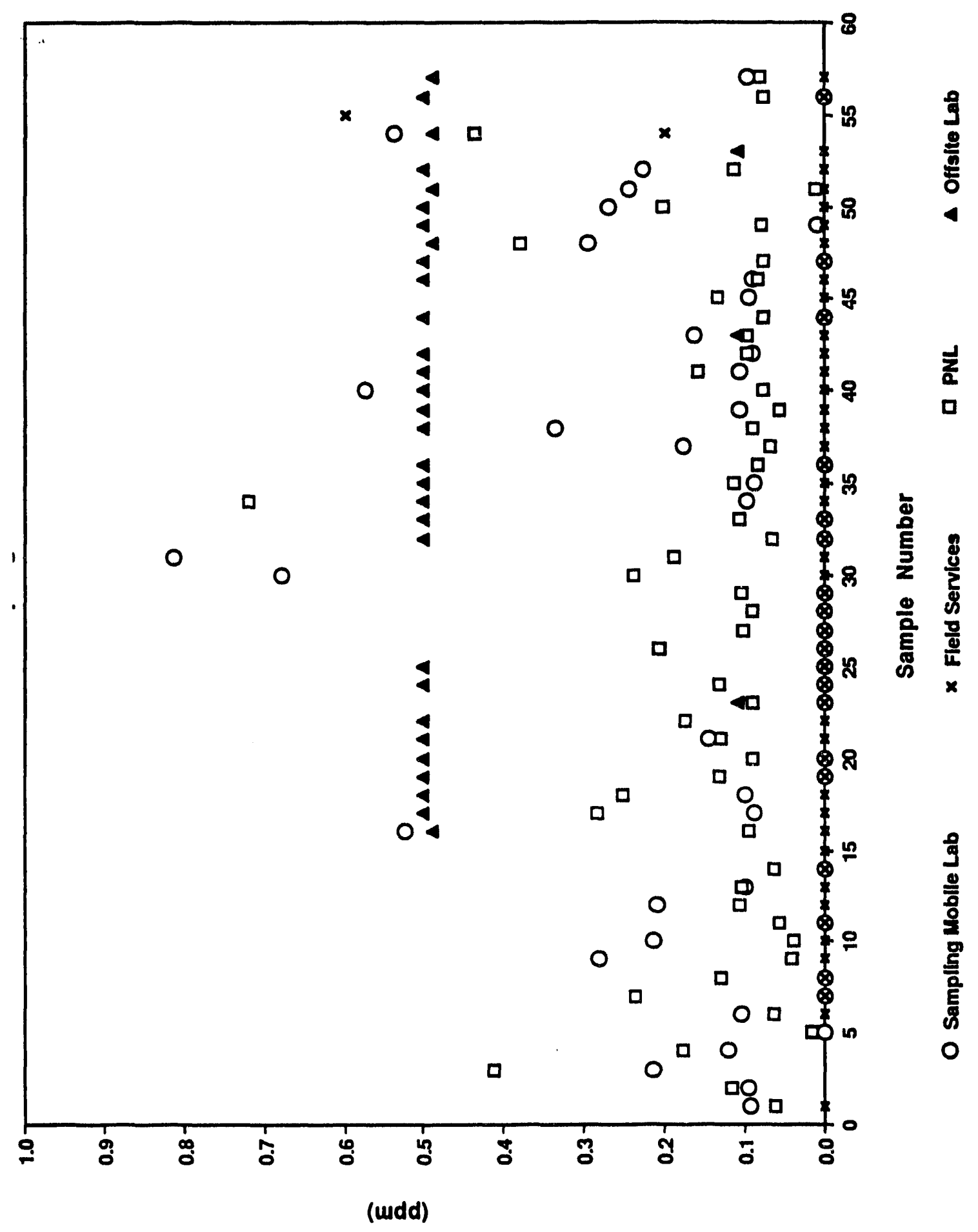


DOE/RL-93-64, Rev. 0

Figure 5. Field Screening Chromium(VI) Spiked Sample Results.

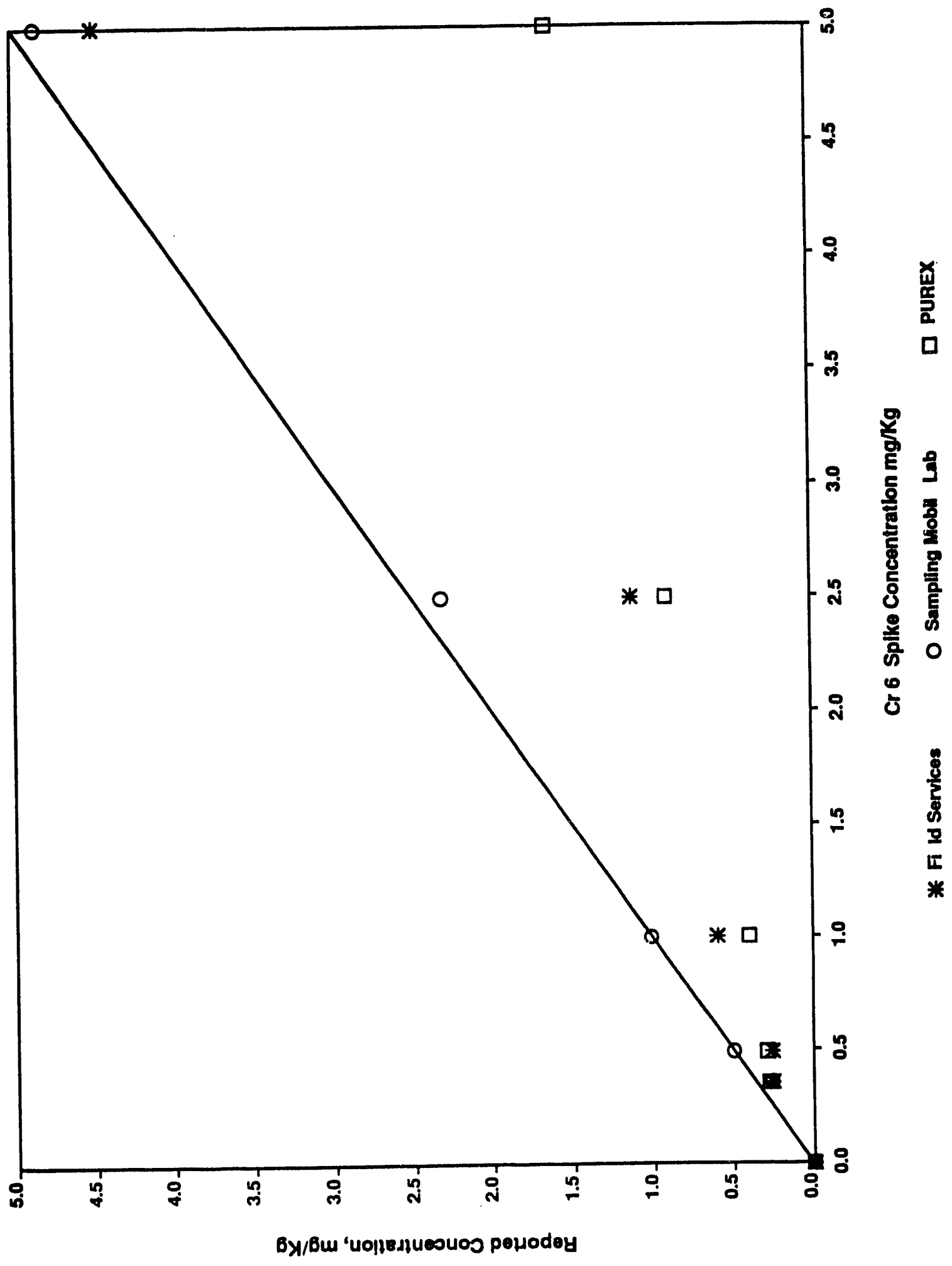


DOE/RL-93-64, Rev. 0

Figure 6. Total Chromium Sampling Comparison.

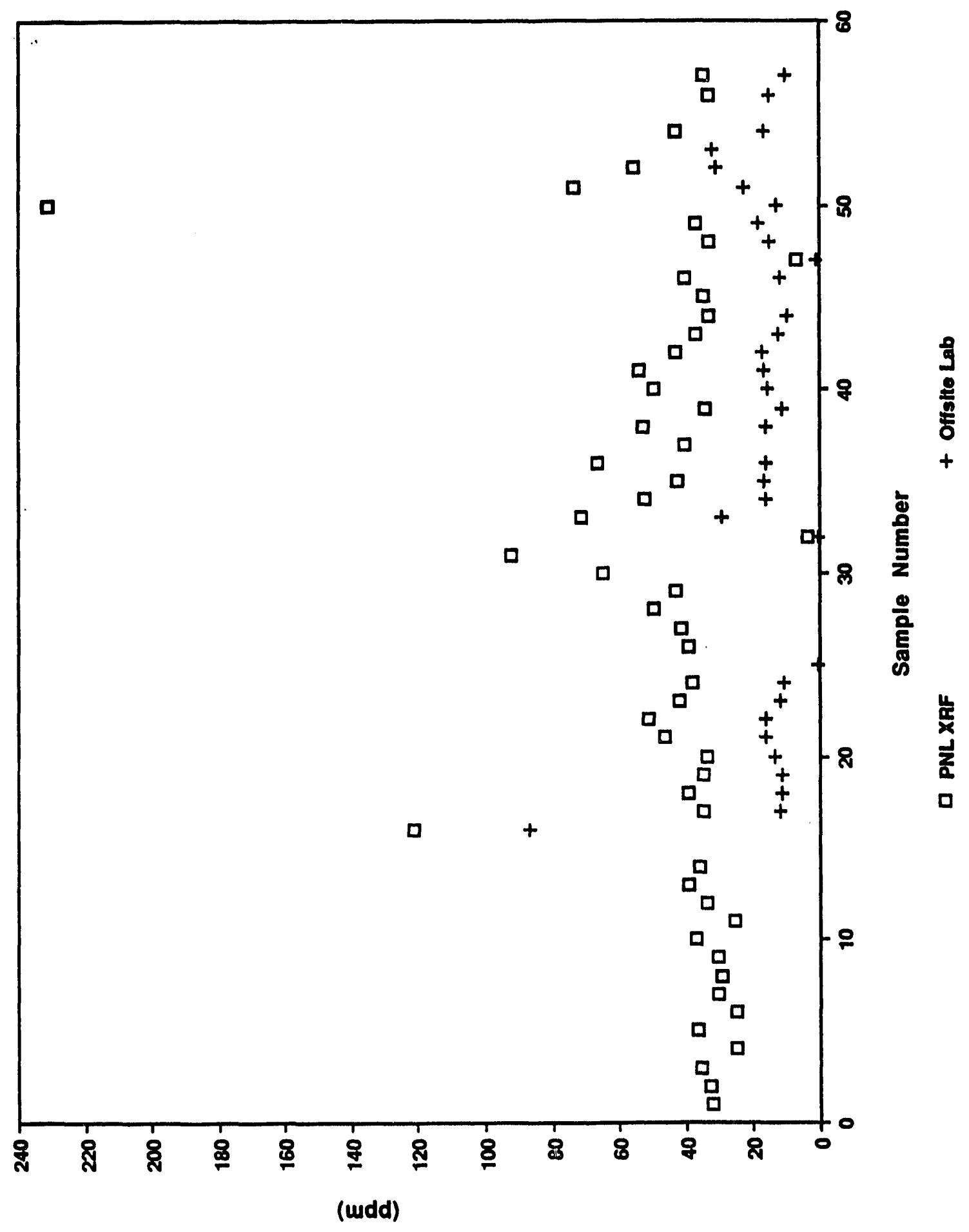


DOE/RL-93-64, Rev. 0

APPENDIX A

ACTION AGREEMENT MEMORANDUM

A-1 


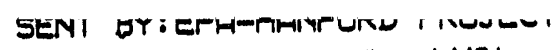

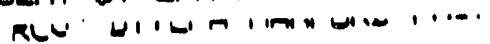

$03: 08.93 \quad 30: 17$

$\ddot{R L}-93-63$, Rev. 0

wuva: uั.

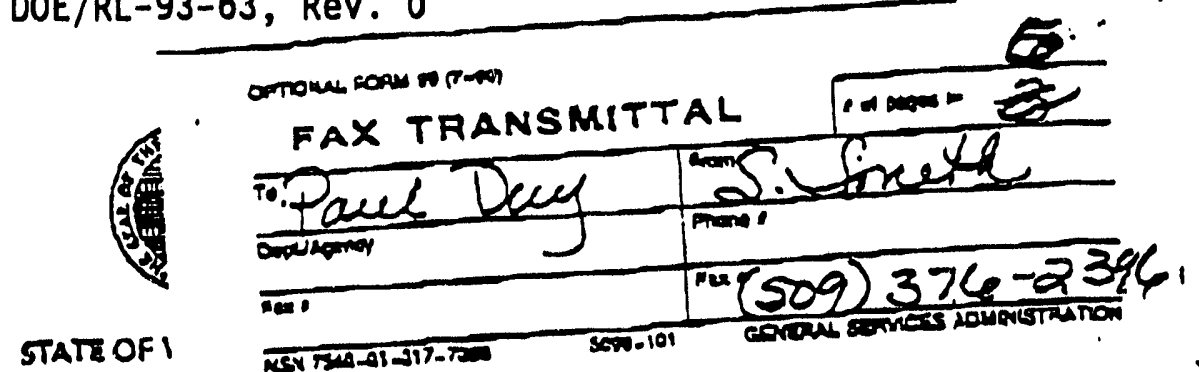

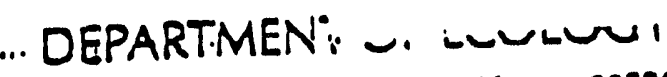

7801 W. Clewwater, Suile 102 - Kennewick, Washington 99336 - (509) $546-2990$

Kazch 8, 1993

Mr. Loo E. LiEele, Assiseanc Manager

Environmanesl Mrragemant

U.S. Depertwenc of Energy

P.O. Box 950, A3-42

Rlahland, HA 99352

Dear Mr. Lifgla: Re: Action Kamorandum Approval: Sodium Dlchromace Berrel
Landelli, U.S. Doparement of Eporgy Hanford Sice, RLchland, ViA

Th1s laetar consteutes approval of the subject Acelon Mamorandum.

I. FORPOSE

The putpose of chls action is to mielgaco any threat to public boalth and the anvironment from the Sodfum Dichromate Barrel Landfild, and co

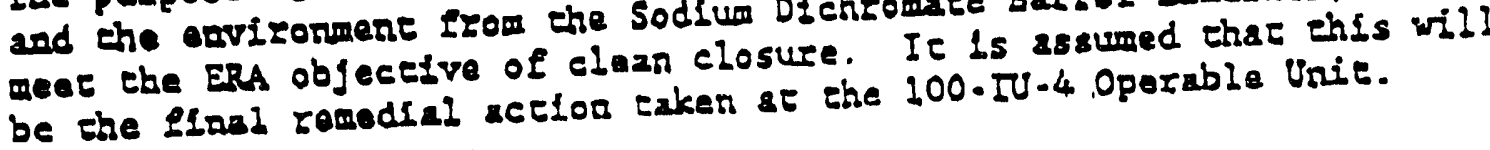

\section{BMCREROOTD}

Pursuans to the Comorehangive Snyironmencar Renponse, Compensacton and

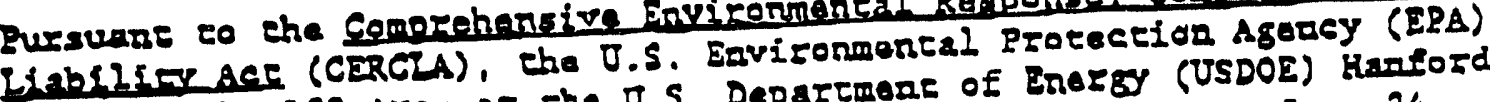

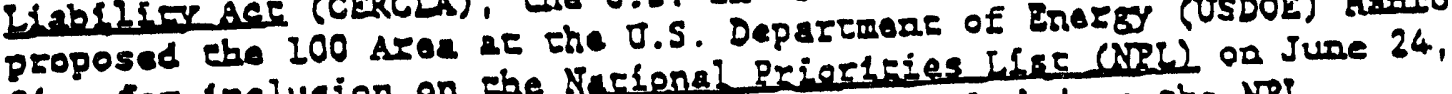
sice for inclusion on the Nurienal priorlfiesched on the NRL.

1988. In November 1989, the 100 Ares was 'Include

\section{A. Sire Descetiption}

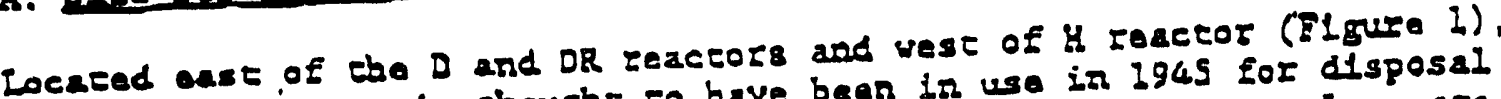
chis landflil urea is ehoughe to have been in uso in 1945 for disposal of dlsearded and eruahed barrals. The londfill aros is the solo waste steo whin the $100 \cdot I U-4$ Operable unit.

tisterieal documezertion for the atte (sice dimensloos, usage, and ursta

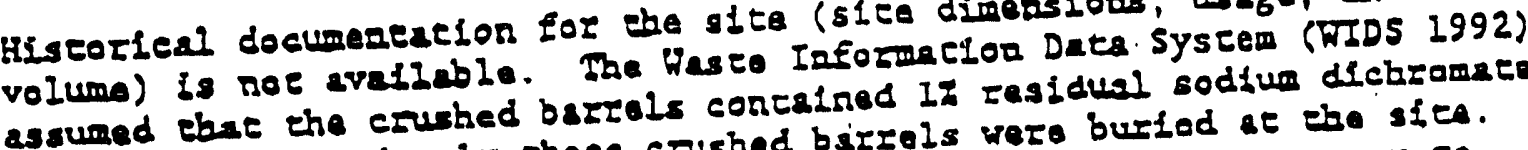
se burlal time and only these erushad birzols wero burfod at the sfea. schromace used us an addiftve to zactor cooling wacar to prevene pipe corroaton. 


$$
\text { DOE/RL-93-63, Rev. } 0 \text {. }
$$

Le E. IEtLa

Page 2

Karch 8. 1993

In addlefon to Sodfun DLebromete Bertels, tho site 2150 includes homascad surface debris, berbed and fencing wira, scove plpe. and various tin cans. The site why heve been used as a general landfill. Burial depth is shallow since visurl inspactlon finds lafge eqounts of berral debris on the surface. The limited field inonstfgation also proved the dapth of burlal is around 6.5 feet. The oite fa ractangular In shape, and is about 1,500 feec long by 300 feet wide. The Imediate srea surrounding the sico stili shows ovidance of its originsl egrleulterral una; fleld rows ere noticrable on tho wast perfuterer.

Chromium (Cr) exises in the 100-hR-3 Opersblo Unie area groundwacar, but this site is not che suppected source. Groundwacer samplos from the slee's monicorting well (699-93-46) do nor repore derocrable levals of chromiun. The groundwaser dapth is 29 fooc. Site radlaclon survey Indicate that radfacion lovelg aro not lo axcess of the natural background lóvols. The slee coreains weny bara pacches (most fin cizcular shepe with diameters from about one foot to tan feer) surroundod by "healchy" chene grass. A tlacford Site survey identifled ereas concalning this "reeural pbenomena" ac several ofher localicles.

\section{B. Sica Gharzcreziration}

Sice charactartzacion activities included wo goophyzical, noninczusivo, ground-pecetrating radar and electromagnetic induction survoys, surface debris collection, samplo Exencties, suple plt, and soli sampling.

The flest geophyslcal survey idenclfled many subsurface anomalous 20 nes. The survay 1dantifiad the need to remove the surfsce dobris (abour 41 barrels and homestead dabris) which incerfered with the survoy. Fiold serouaing and offsfee laboratory analysis sample collectlon oceurrod durlag surface dabris elearup. The secord geophysleal surray providod moze derall, eleazar asomaly delineation, ad defectlon of abour 144 cmall and largo anomalles. The survey lncerproted mose of theso as mecallif debris. Based on survoy rosules, linleed field inveselgactons wero carfled out.

Two sumplo treaches and one sample pit ware dug to confiza the survey fledings. Numerous crushed drums were found to a depth of about 6.5 feer in both the Erenches. A crushed drum with tho rording "Sodfun Dichromate Crystels" scill leglble was discovered in Erench 2.

Soll semples wero collected from the surface, wo tear crenches, and ose cent ple. Also during surface debrfs cloanup, rurface samples were obtzirad for analyais. Tha samplos were altbar flold sereened for CIt6

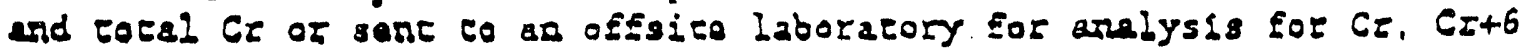
and game enffeling radiomuclides. 
Loo E. LEELe

Page 3 .

Kareth 8, 1993

All samplea vace field survayad for zadiation. The field inserumencs did not docece any radfector lavels and showad detectable Crt6 levels of less chan five ppo. Leboracory analysis shows a maximim concentration of coeal Cr at 56.3 ppre and $13: 6$ ppm of $6 x+6$.

\section{THREAT TO PUBLIC BENITE OR TILEARE OR TER ENVIROKOENT}

\section{A. Bresint condietens}

Ifoicod feld Invesefgatlons vare carried oue in tho Sodium Dichromase Barrel Inedelli. There ere abour 144 anomelles, and full scale

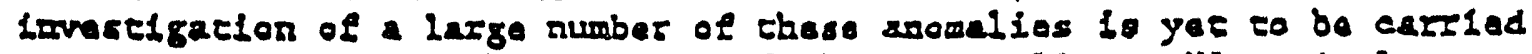
our so derermine all the conrenes of these spomalies. Histortcal documentertion for the slse (usage and waste type, wasce volume) is not arallable. WIDS 1992, assumes that the erdshed berel contafned ix rasidual sodfum dichromete at the buriel cime and that only crushed barrel vere burfed ar be size. This essumpiolon sooss to be correct as avidarced from the ILnsead field Investigation of excavation of wo test Erenches, which revealed numerous crushed drums in the crenches. Oaly one crushed drum vith the vording "Sodium Dichroase Crysexls" still

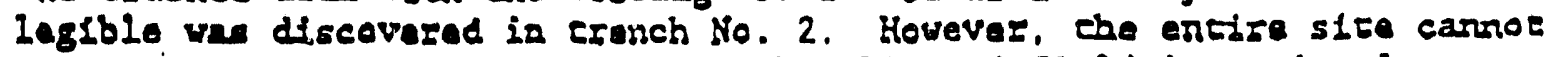
bo assumed to be the same basod on this limltad fleld investigation. The aumpla analyatir resules are voll bolow the Model Conerol Toxte Ace (IICA) Residenelal Soll Clean-up chromlum seandard of $100 \mathrm{ppm}$. However. It is soo oerly to conelude thee shera is no chraec or dnnger to the public healch or envisongent from concaminanes st the slee without full invesefgacion of all the axomalias. The ERA's goal is to achleve clean closure and ungesterfeted use of land. Public comerents ara in lavor of complece removal of these drums from the slee.

\section{B. Aopliterble or Relerant and Appropriace Recriramanes}

The ERs will be conducted in eccordance with 40 CFR 300 subpare E; th

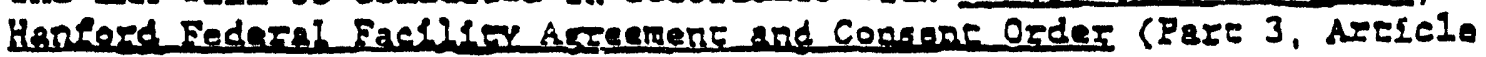
XIII, Suceion 38); the Cemerchensive Bnvi zonmencal Response Compensaction and Liablifey act of 1980 (CERCIA), and the Seace of Washingeon Hedel Toxier. Conezel Aes (MTCA, Chapear 173.340 HAC).

\section{IN. RROROSED NTION AND ESTINATED COSTS}

Westrnghouse Huford company (WTE), as cho USDOE conerxctor, prapared an enginaerlng ovalunefon/cose anslysis (EE/CA) concernizg tachnologies

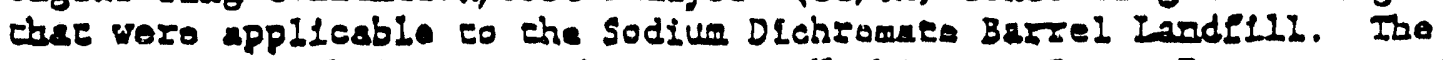
proposel was submieted to the ERA and Vusiningron Staco Deparements of Ecology (Ecology) by USDOE for perallel roviow, and wa aiso ande arallable for public comment for tho poriod of thirty (30) daya. The EE/CA proposad three remodial aefion al cormacivos. They are: No-Acefon Alcemarlve, Samplo All Aromalifs, and Excrvate and Dispose at Caresal 
Leo E. LIEElo

Page 4

Yareb 8, 1993

Lendfild. Ten (10) publle commenes ware received, including coments Erom Confecaraced Iribes and Bandi of the Yakima Indian Nazion. One public coment supporeed a "no acefon alcernaciva," while the aefority (about $70 \%$ of the cocal rasponse) optad for cocel axceverion and removal of berrels from the sife. The zost of the public commencs ware deemed not relevane. The following proposed aleernactves vero ovaluaesd.

A. Ho Acfion. The very lioleed nature of the fleld setivity doos not Juetify the action. Also, tho oxiselng sampling deta is not sufficlant for Ecology zegrlacore to support this alcernative.

B. Sample Alt Anemalies - The purpose of sempling all anomalles (about 144) is to further confism that tho sico coneulns no regulaced huzardous vante. Sample collection vill zequire a small backhoo and dust concrol devices. AII excavacad debrls will be reburied where found. The debris type will be visualiy idencleled at eseh anowaly locaclon. If tho anomaly is a erushed drum(s), sampla collection will be for fleld sereaning and offolte leborztory analys18. If the anomaly is homestand debris, no samplo collection wil occur. When all the analysis resules are recaived and show that the olto is contuminate free, all maps will be upgraded. A noto will be added that the slte contained burled creshed drues and that $C I$ and $C E+6$ levels azo vithin beckground levels. Reseeding of the dfsturbed sample erean will be done. The cocal cost for this al earative la eerimated at $\$ 288,990$.

This alcarnscive will conflam whother che sita contains any regularad berardous vaste. The supling vill aleo require cocal screentag for meels and orgaries, and arelysis for selected samplos. The cost is mueh blcher than the fblid eleermative of total excavarion and removal. Also, ehis opelon does aot address fuenre problem(s) that may ariso. Ite public comente are againse this opelon. This opelon does not meet the orfginal ineane of ehe IRA, which is clean closuro of the site.

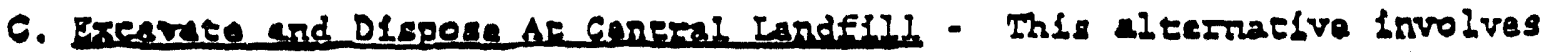
axcaraclon of all anomalles, placlag the debrla in durp enseks and dsposal at eho ceneral landfill. Samplo collocelon will occur if Alscolored soll or dobris ocher than crushed drums or homestand eypes appore during the excevetions. Area scabilization and reseeding will follor excavaefon. The coeal cose 18 eseluatod ae $\$ 192,140$. The claunp activlsy wiIl eake aboue six (6) weeks, depondlag on veacher conderloos:

Thls alcerrative is cechalcally teasible and cost effective. It will bo effactive in meeting the aRA goal by removiag all potezelal concanination. Ible aceson is also tho proferred al cernacive by the public, and may allow unranericted use of the land. Conflzoncory samplifog mest oceur to shou that in site is cl an. 
Loo E. L1EeI.

Rage 5

Berch 8, 1993

\section{Implemenertion}

Labor. . . . . . . . . . . . . . . . . \$45,400

Murerials and suppliew.......... 5,000

Aralyeleal servieas............. 15,400

Iquepmenc Iassing............. 18,000

Coneral tande111.............. 54,000

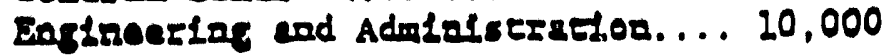

sub Total.................. $\$ 147.800$

308. Conelogeney............... 44,340

TOTR $\ldots \ldots \ldots \ldots \ldots \ldots \ldots \ldots \ldots 22,240$

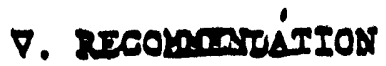

Thle doclsion doeument recommends the axcavition of all anomallas and disposal of the wetarisis at the eanezal landelil (Opelon C) for the Sodium Dichromate Barrol Landell of tho USDOE Hanford SLEe In Rlehland, Wh. Ihls deelslon vas developed in accordance wien CERCLA as amonded by

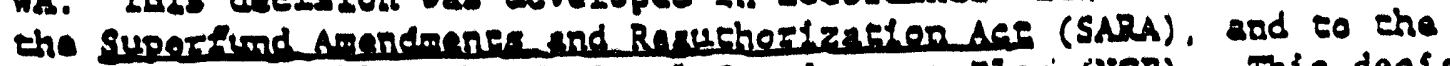

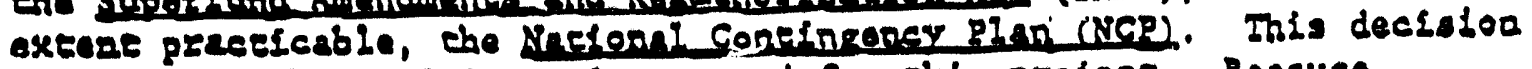
is besed on the adminlatrative racotd for this projuet, Bocester

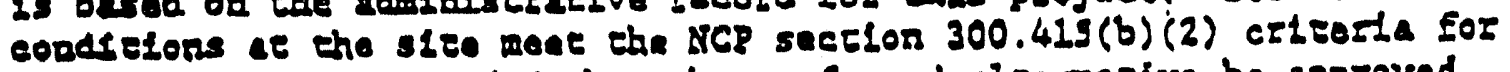
action, It is gocommanded that the preferted alcermative be approved.

If you beve any Eureher questions, please coneace Dave Nylandar ae (509) 736-3000.

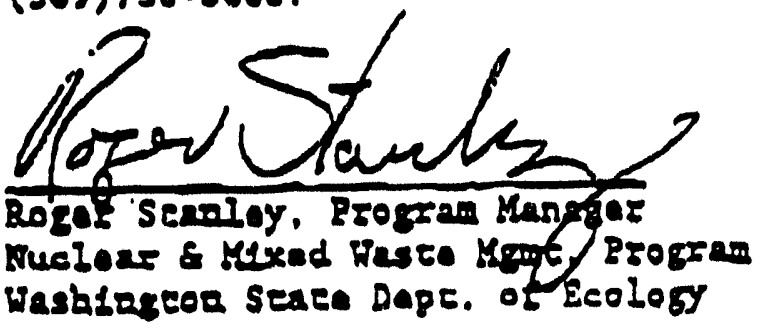

RS: :E

co: Robere $R$. Stavare, üsDOE

Baul DaY, ERA

Paul Beaver, ERA

Dere Junser, Ecology

Dave Nylandar, Ecolory

Darel Ienl, Ecology

Dib Gorwams, Ecoloy

Admiofserativa becord (Sodfum DLehromat ERA)

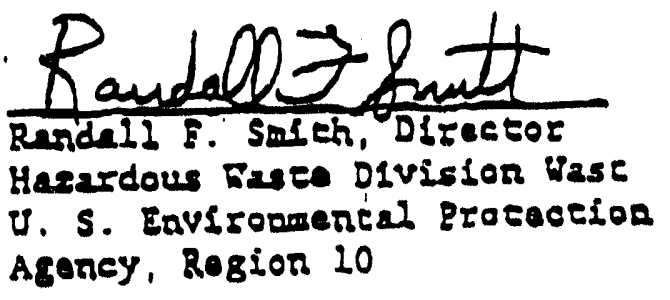


DOE/RL-93-64, Rev. 0

DISTRIBUTION

Number of Copies

Onsite

31

U.S. Department of Eneroy. Richland Field Office

J. K. Erickson (30)

A5-19

Public Reading Room

A1-65

1

Pacific Northwest Laboratory

Hanford Technical Library

P8-55

29

Westinghouse Hanford Company

D. R. Baker

$\times 7-02$

T. L. Bennington

H4-16

H. D. Downey

K. A. Gano

H6-27

C. E. Heiden

$\mathrm{X} 0-21$

G. C. Henckel

H6-04

R. P. Henckel

H6-04

W. L. Johnson

H6-02

D. G. Kachele

H6-04

R. C. Roos

$54-67$

D. B. Tullis

H6-04

P. J. Valcich

L6-51

EPIC (7)

ERC (G. Fitzgibbon)

H6-04

H6-08

ERE (F. Stone) (2)

H6-07

ERE Project File

H6-01

ER Program Office (2)

H6-03

IRA (3)

H6-27

Resource Center

H4-17

N3-05 

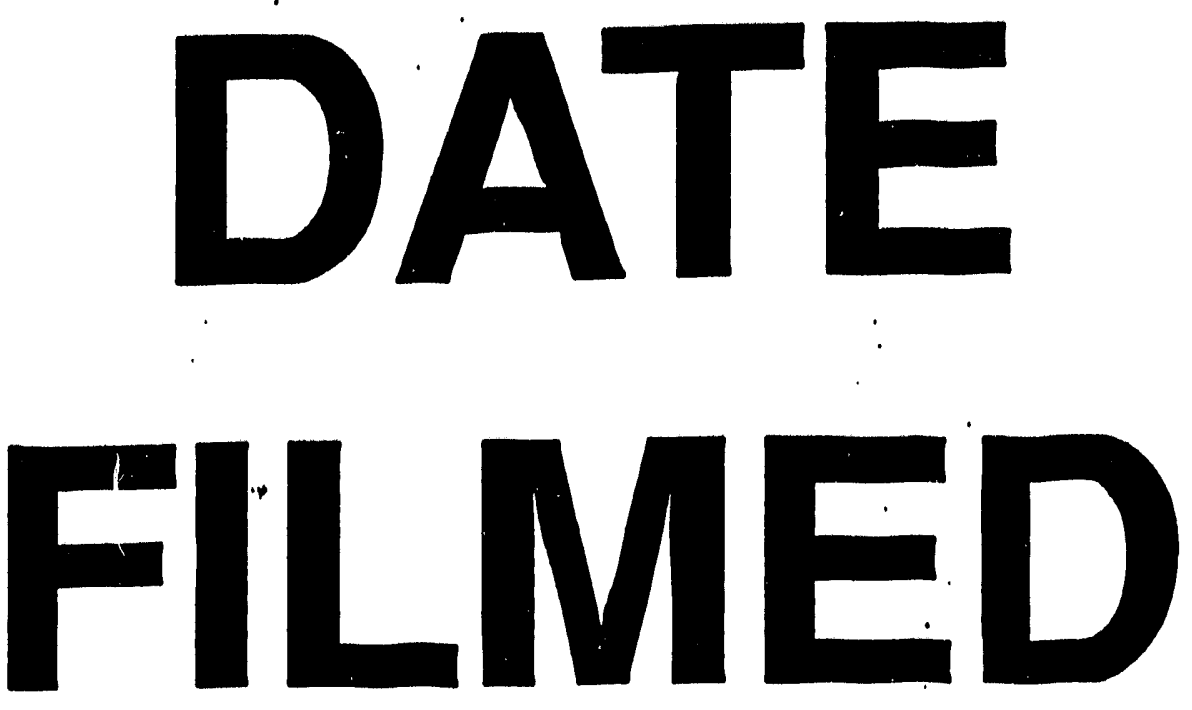

$12 / 10 / 93$
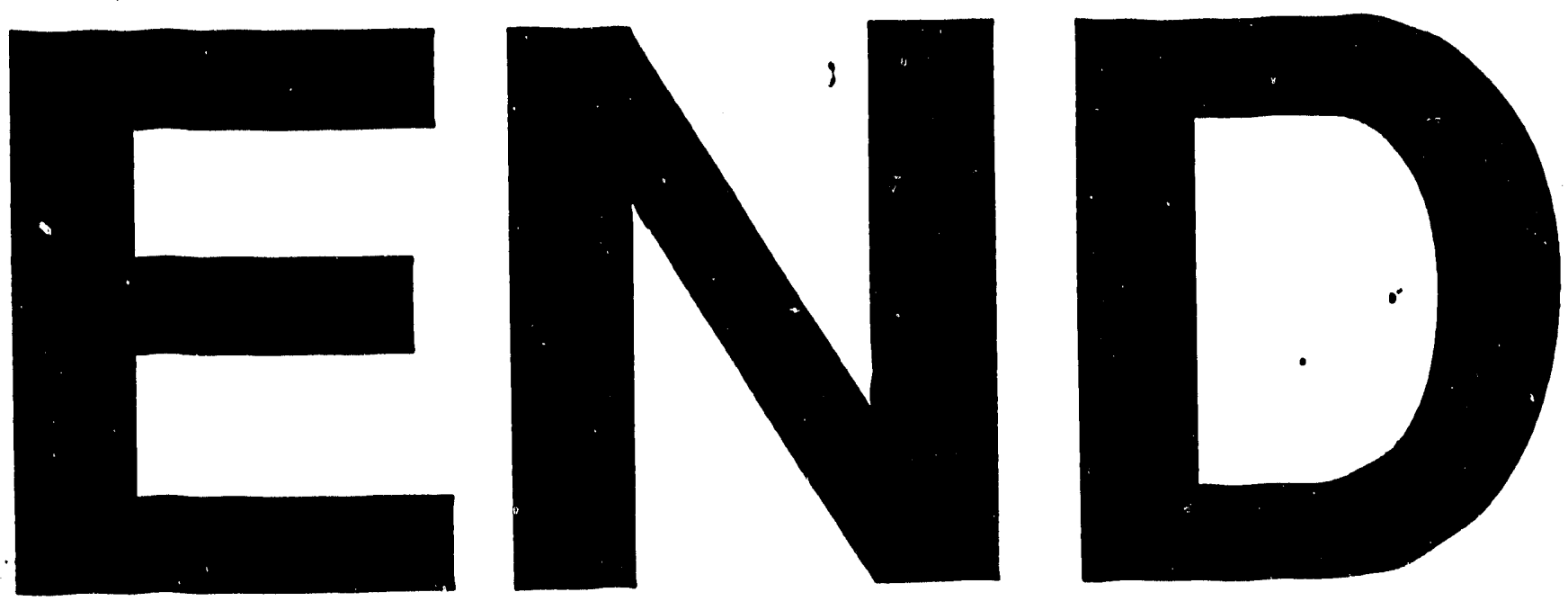